\title{
ARTIKELEN
}

\section{Bevraging van de Belgische advocatuur over bemiddeling: eerste resultaten}

\author{
Tom Wijnant
}

Aan de Universiteit Gent is in 2017 empirisch onderzoek uitgevoerd naar de houding van de Belgische advocatuur tegenover bemiddeling in de huidige en toekomstige juridisch-maatschappelijke context. Deze bijdrage biedt eerst een toelichting bij de achtergrond, doelstelling en methodologie van het onderzoek en licht vervolgens een tipje van de sluier rond de onderzoeksresultaten met enkele eerste, opvallende waarnemingen.

\section{Doelstelling van het onderzoek}

Bemiddeling wordt in België amper aangewend bij de afhandeling van conflicten, terwijl de rechtbanken overbevraagd blijven. ${ }^{1}$ Het gebrek aan medewerking van de advocatuur wordt steevast opgeworpen als een van de mogelijke oorzaken. ${ }^{2}$ De Belgische advocaat zou zich sceptisch opstellen tegenover de waarde en het nut van bemiddeling en zou dit traject zien als een bedreiging voor het eigen professionele functioneren. Ook het gebrek aan kennis over bemiddeling bij de advocaten zelf zou bijdragen aan deze weerstand binnen de advocatuur.

Medewerking van de advocaat kan nochtans van groot belang zijn indien men, waar mogelijk en opportuun, de potentiële voordelen van bemiddeling in toenemende mate wenst te benutten. De advocaat is immers een uiterst belangrijke schakel in de hedendaagse conflictoplossingsketen: wanneer een partij verwikkeld raakt in een conflict, zal zij in heel wat gevallen eerst een toevlucht nemen tot

1 Jaarlijks vinden in België naar schatting slechts 5.000 bemiddelingen plaats, terwijl de hoven en rechtbanken meer dan één miljoen vonnissen en arresten vellen. Zie bMediation, Bemiddelingsbarometer 2016, www.bmediation.eu/images/stories/publications/bemiddelingsbarometer \%202016\%20nl\%20final.pdf (consultatie 29 maart 2018), 6 en K. Geens, Het Justitieplan - Een efficiëntere justitie voor meer rechtvaardigheid, https://cdn.nimbu.io/s/1jn2gqe/assets/Plan_ justitie_18maart_NL.pdf (consultatie 3 april 2018), 14, nr. 15.

2 Zie o.m. P. Taelman \& S. Voet, Mediation in Belgium: A Long and Winding Road, in: C. Esplugues \& L. Marquis (eds.), New Developments in Civil and Commercial Mediation - Global Comparative Perspectives, Cham: Springer 2015, p. 109; K. Verwaest, Trajectbemiddeling als brug tussen advocaat en bemiddelaar, Juristenkrant 2014, afl. 296, 12; S. De Bauw \& B. Gayse, De rechter en bemiddeling: nood aan nieuwe attitudes en vaardigheden?, in: R. Van Ransbeeck (red.), Bemiddeling, Brugge: die Keure 2008, p. 137; R. Boone, Overregulering doodt de ethiek [interview met A.L. Verbeke], Juristenkrant 2015, afl. 318, 9 en Hoge Raad voor de Justitie, Bemiddeling: Geloven en gebruiken - ideeëndebat over de bemiddeling, 30 april 2010, www.csj.be/sites/5023.b. fedimbo.belgium.be/files/press_publications/2010-04-30-nl-bemiddeling.pdf (consultatie 29 maart 2018), p. 60-61. 
haar raadsman. ${ }^{3}$ Die raadsman verleent vervolgens als 'eerste rechter' niet alleen advies over de juridisch-inhoudelijke aspecten van het conflict, maar zal de partij ook doorverwijzen en begeleiden naar het meest gepaste traject voor de oplossing van het geschil. ${ }^{4}$ Net omwille van de primordiale rol die de advocaat speelt bij de adequate doorverwijzing naar bemiddeling en omdat het gebrek aan medewerking binnen de advocatuur bijgevolg weleens een van de voornaamste struikelblokken kan zijn in de ontwikkeling van bemiddeling, is het nuttig de bovenstaande premisses over de houding van de Belgische advocaat te toetsen aan de hand van empirisch onderzoek waarin enkel advocaten werden bevraagd.

Het onderzoek heeft tot doel om de houding van de Belgische advocatuur tegenover bemiddeling waarheidsgetrouw in kaart te brengen. De resultaten kunnen de wetgever bewust maken van reële impedimenta die de ontwikkeling en stimulering van bemiddeling in de weg staan. Tegelijk biedt dit onderzoek de mogelijkheid om een aantal bekommernissen en belangen van de advocatuur te identificeren. Dit is van essentieel belang: indien de beleidsmakers willen dat de Belgische advocaat op de bemiddelingstrein springt, zullen zij diens legitieme belangen ernstig moeten nemen en waar mogelijk verdisconteren.

Het onderzoek kijkt bijgevolg niet enkel naar de actuele toestand, maar polst eveneens naar het draagvlak binnen de advocatuur voor mogelijke denkpistes die beogen bemiddeling te laten evolueren naar een traject dat als een volwaardig alternatief voor overheidsrechtspraak wordt gezien en gebruikt. Hierbij werd doelbewust aandacht geschonken aan de rol die de advocaat zichzelf wil aanmeten in de toekomst van conflictoplossing.

Deze bijdrage kwam tot stand in het raam van doctoraatsonderzoek dat de auteur voert aan de UGent betreffende 'suggesties tot optimalisering van de buitenge-

3 Zo blijkt uit Nederlands onderzoek dat $12 \%$ van de burgers met een potentieel (juridisch) probleem de stap zet naar een advocaat. Dat is een erg behoorlijk aandeel, rekening houdende met het feit dat uit hetzelfde onderzoek bleek dat een kwart van de respondenten overwogen heeft of geprobeerd heeft een rechtshulpverlener in te schakelen, maar dit uiteindelijk niet nodig vond, onder meer omdat men het probleem zelf of met anderen had kunnen oplossen (28\%), men liever geen slepende juridische procedure wilde (17\%) of omdat men nog even wilde afwachten (18\%). Het ligt inderdaad binnen de verwachting dat burgers geen advocaat zullen willen inschakelen wanneer men minstens nog het gevoel heeft dat men het probleem zelf kan afhandelen. Ook de verwachte hoge kostprijs van juridische bijstand is vanzelfsprekend een drempel (18\%). Respondenten die aangaven geen enkele stap ondernomen te hebben, gaven eveneens aan dat men dat niet nodig achtte, omdat het probleem zichzelf had opgelost (39\%) of omdat het geschil van dien aard was dat verdere stappen niet de moeite waard waren (21\%). Ondanks het gegeven dat een groot aandeel van de problemen ook zonder bijstand door een advocaat kon worden opgelost en dat financiële drempels de toegang naar de advocaat ongetwijfeld bemoeilijken, blijft het percentage burgers dat wel een advocaat inschakelt redelijk hoog. In die gevallen speelt de advocaat een grote rol in de keuze van het traject voor geschiloplossing. Zie M.J. Ter Voert \& C.M. Klein Haarhuis, Geschilbeslechtingsdelta 2014 - Over verloop en afloop van (potentieel) juridische problemen van burgers, Den Haag: Boom Lemma 2015, p. 15, 81-82, 87-90. Voor België zijn geen data voorhanden.

4 De advocaat kan de cliënten in principe doorverwijzen en begeleiden binnen een heel spectrum aan mogelijke trajecten: rechtstreekse of collaboratieve onderhandelingen, minnelijke schikking door de rechter, arbitrage, overheidsrechtspraak, gerechtelijke of buitengerechtelijke bemiddeling,... 
rechtelijke bemiddeling in België, met focus op een faciliterende rol van de advocatuur'. De finale doelstelling is dan ook om op basis van de empirische vaststellingen over de houding van de Belgische advocatuur concrete aanbevelingen te formuleren om een gepast gebruik van bemiddeling aan te moedigen. Deze aanbevelingen moeten er tegelijk voor zorgen dat de advocaat bij bemiddeling een volwaardige partner wordt, die zijn doorverwijsfunctie naar alternatieve trajecten maximaal vervult in situaties waarbij een beroep op de overheidsrechter niet het meest geschikte traject blijkt te zijn.

\section{Methodologie}

Alle Belgische advocaten werden bevraagd via een online enquête. De keuze voor dit medium is gerechtvaardigd doordat het kostenefficiënt is en toelaat om vrij eenvoudig een breed publiek te bereiken. Een schriftelijke enquête vermindert bovendien het risico op sociaal wenselijke antwoorden en een ongewenste invloed van het gedrag van de onderzoeker op de antwoorden. ${ }^{5}$ De vragenlijst werd initieel ontworpen in het Nederlands, waarna de tekst vertaald werd naar het Frans. Zowel de originele Nederlandstalige tekst als de Franstalige vertaling werd meermaals grondig nagelezen en gecontroleerd door een multidisciplinair panel van academische professionals met ervaring in juridisch, sociaalwetenschappelijk onderzoek en/of data-analyse. De vertaling en overeenstemming tussen de Franstalige en Nederlandstalige tekst werden bovendien diepgaand en onafhankelijk van elkaar gecontroleerd door drie personen die omwille van hun professionele of persoonlijke achtergrond beschikken over een perfecte beheersing van de twee talen.

Het onderzoek vond plaats met de herhaalde steun van zowel de twee Belgische beroepsorganisaties voor advocaten (Orde van Vlaamse Balies en Ordre des barreaux francophones et germanophones) als van de minister van Justitie. Om kruisbestuiving mogelijk te maken, werden de voorlopige versies van de vragenlijst dan ook doorgestuurd naar de ordes en het kabinet Justitie. Zij werden uitdrukkelijk uitgenodigd om opmerkingen en aanvullingen te formuleren. Op basis van hun input $^{6}$ is de vragenlijst verder op punt gezet.

De finale vragenlijst bestond uit drie luiken. In het eerste luik werden algemene vragen over het profiel van de respondenten gesteld. Vervolgens volgde een luik over bemiddeling in het huidige Belgische recht en de rol die bemiddeling vandaag speelt in de praktijk. Daarbij werd in eerste instantie het kennisniveau van de respondent over bemiddeling onderzocht aan de hand van twintig 'juist/fout/weet het niet'-vragen over het Belgisch bemiddelingsrecht de lege lata. Vervolgens kreeg de respondent vragen die polsen naar waardeoordelen over bemiddeling in de huidige context. Het derde en laatste luik bevroeg de advocaat over de toekomst van bemiddeling in België. Ook daar werden eerst bepaalde stellingen onderwor-

5 D. Baarda \& M. De Goede, Basisboek Methoden en Technieken, Groningen: Wolters-Noordhoff 2001, p. 224 en 227.

6 De ordes hadden niet de mogelijkheid om vragen te schrappen, teneinde de onafhankelijkheid van het onderzoek te vrijwaren. 
pen aan het waardeoordeel van de respondent. Tot slot werden concrete toekomstige maatregelen voorgesteld, waarbij het draagvlak binnen de advocatuur werd onderzocht. De respondent kreeg daarbij telkens de gelegenheid om zijn/haar antwoord vrijuit te beargumenteren wanneer dat nuttig werd geacht. Hierbij kan nog worden opgemerkt dat bij aanvang van het derde luik de belangrijkste principes van bemiddeling in het huidig recht kort werden uiteengezet. Die sequentie was noodzakelijk om de antwoorden op het derde luik niet te compromitteren. Deze werkwijze bood de respondent meer bepaald de mogelijkheid om de stellingen over de toekomst van bemiddeling met een zekere kennis van zaken in te vullen, zelfs zonder relevante ervaring.

De definitieve versie van de vragenlijst werd vervolgens geprogrammeerd met behulp van het programma LimeSurvey en uitvoerig getest op de correcte verwerking van de data. De survey was beschikbaar van 20 april tot en met 21 juli 2017. Deze behoorlijk lange termijn was wenselijk, temeer omdat deelname aan het onderzoek ongeveer dertig minuten in beslag nam. De termijn moest voldoende mogelijkheden bieden om deelname aan het onderzoek te combineren met de beroepsuitoefening van de advocaat. Om dezelfde reden was het mogelijk om een onvolledig ingevulde vragenlijst op te slaan en later af te werken. Advocaten konden volledig anoniem deelnemen aan het onderzoek om sociaal wenselijke antwoorden te vermijden. ${ }^{7}$

Er werd doelbewust voor gekozen om alle advocaten, die aangesloten zijn bij een Belgische orde te betrekken bij het onderzoek. Enerzijds bleek de vooraf bepaalde samenstelling van een representatieve steekproef onmogelijk (zie infra), anderzijds kregen hierdoor alle Belgische advocaten een platform en werden potentiële deelnemers met waardevolle inzichten niet op voorhand uitgesloten.

Om ruchtbaarheid te geven aan het onderzoek en om deelname te stimuleren, kon opnieuw op de steun van de ordes worden gerekend. Zij hebben een oproep tot deelname rondgestuurd via hun nieuwsbrieven (OrdeExpress/La Tribune). Deze kanalen leken interessant, omdat daardoor alle aangesloten advocaten snel en goedkoop konden worden bereikt. Desondanks bleek de effectiviteit van de oproep beperkt, waardoor het noodzakelijk werd geacht om ook andere kanalen aan te spreken. Nadat schriftelijk en/of telefonisch contact opgenomen werd met de dertien Nederlandstalige en de twaalf Franstalige balies en de Orde van Advocaten bij het Hof van Cassatie, besloten alle lokale balies hun medewerking te verlenen en eveneens een oproep tot deelname te verspreiden via mailinglijsten, nieuwsbrieven en/of intranet. Bij aanvang van de gerechtelijke vakantie werd via de lokale balies nog een herinnering tot deelname doorgestuurd. Ook deelnemers die hun voortgang in de enquête hadden opgeslagen maar de vragenlijst nog niet hadden afgewerkt, kregen een herinneringsmail. Deze werkwijze maakt het opnieuw mogelijk om een zo breed mogelijk bereik te hebben, rekening houdend met de budgettaire beperkingen van het onderzoek.

Om deelname aantrekkelijker te maken, konden respondenten die de enquête hadden afgerond ook deelnemen aan een wedstrijd waarbij verschillende prijzen

7 D. Baarda \& M. De Goede, Basisboek Methoden en Technieken, Groningen: Wolters-Noordhoff 2001, p. 224 en 227. 
(o.m. cinema-tickets, boekenbonnen en jaarabonnementen op juridische tijdschriften) via een onschuldige hand uitgedeeld werden. Deelnemers konden daartoe hun mailadres achterlaten op het einde van de survey. Dit mailadres werd vanzelfsprekend niet gekoppeld aan de individuele antwoorden.

In totaal werden 713 deelnames geregistreerd, waarvan uiteindelijk 490 responsen in aanmerking werden genomen om zinvolle statistische analyse mogelijk te maken. Deze selectie werd gemaakt aan de hand van een objectieve maatstaf, met name het ingevuld hebben van een bepaalde vraag in een gevorderd stadium van de enquête, waarvan de antwoorden dienden als afhankelijke variabele in de analyse. Wie daarvoor geen scores had, kon bijgevolg niet bijdragen aan de analyse en werd weggefilterd. De responsgraad op basis van de in aanmerking genomen data komt neer op ongeveer ${ }^{8} 2,64 \%$ van de totale populatie advocaten.

De dataverwerking en statistische analyses werden vervolgens uitgevoerd in samenwerking met het Centrum voor Statistiek, het expertisecentrum van de UGent dat de onderzoekscentra voor statistiek uit de verschillende faculteiten verenigt en dat onder meer ondersteuning biedt aan doctoraatsonderzoekers bij statistische data-analyse.

\section{Beperkingen van het onderzoek}

De resultaten moeten worden gelezen indachtig de beperkingen van het onderzoek.

Doordat ervoor werd gekozen om alle Belgische advocaten te bevragen via vrijwillige deelname aan een online survey (voluntary response sample), was een zekere vorm van non-respons ${ }^{9}$ en respons-bias onvermijdelijk. ${ }^{10}$ Het viel bijgevolg te verwachten dat advocaten die vrijwillig meewerken eerder zouden behoren tot selecte groepen die meer voeling hebben met bemiddeling. Zo was er - weinig verbazingwekkend - inderdaad een wanverhouding tussen het aandeel erkende advocaat-bemiddelaars in de responsgroep en hun aandeel in de totale populatie (zie infra).

Een mogelijke werkwijze om het risico op bias te minimaliseren, is het gebruik van een eenvoudige aselecte steekproef, waarbij een bepaald aantal advocaten op volledig willekeurige basis geselecteerd worden uit de totale populatie om vervolgens aan het onderzoek deel te nemen. Die werkwijze veronderstelt echter de beschikbaarheid van een volledige, actuele en accurate lijst met (contact)gegevens

8 De ordes maakten bij aanvang van het onderzoek melding van 18.532 aangesloten advocaten (eind 2016). Bij gebrek aan recentere cijfers werd ervan uitgegaan dat dit aantal constant is gebleven tijdens de loop van het onderzoek.

9 Non-respons is het gevolg van het feit dat bepaalde individuen uit de populatie niet bereikt kunnen worden (bijv. door foutieve contactgegevens of omdat zij niet vertrouwd zijn met internetgebruik) of omdat zij deelname aan het onderzoek weigeren. Zie D. Moore, G. Mccabe \& B. Craig, Introduction to the Practice of Statistics, New York: W.H. Freeman and Company 2014, p. 198.

10 D. Moore, G. Mccabe \& B. Craug, Introduction to the Practice of Statistics, New York: W.H. Freeman and Company 2014, p. 194-195. 
van de gehele populatie. Die gegevens waren simpelweg niet voorhanden. Het was a fortiori onmogelijk om een representatief sample samen te stellen via een gestratificeerde steekproef ${ }^{11}$ bij gebrek aan actuele gegevens over de samenstelling van de populatie advocaten (wat betreft geslacht, leeftijd, anciënniteit,...). Om het risico op non-respons en bias toch te verkleinen werden de advocaten via verschillende kanalen opgeroepen en herinnerd ${ }^{12}$ om deel te nemen teneinde de responsgraad te verhogen. Tegelijk werd benadrukt dat ook de visie van advocaten zonder ervaring met bemiddeling van belang was in het kader van het onderzoek. Hoewel een algemeen beschikbare online survey dus zekere risico's inhoudt, werd deze keuze gerechtvaardigd omwille van de kosten- en tijdsefficiëntie en de mogelijkheid om op relatief eenvoudige wijze een breed publiek aan te spreken. Dit paste binnen de doelstelling om aan alle advocaten de mogelijkheid te bieden hun stem te laten horen.

Doordat op voorhand duidelijk was dat een zekere vooringenomenheid van de respondenten een vertekend beeld zou kunnen geven, werden de respondenten uitvoerig bevraagd over hun profiel. Dit liet toe om de onderzoeksresultaten enigszins te nuanceren en om significante verschillen tussen de verschillende profielen via statistische analyse in kaart te brengen.

Het was tot slot onmogelijk om de graad van representativiteit van de steekproef na te gaan. Bij navraag bleek dat geen van beide ordes van advocaten beschikt over actuele gegevens van het profiel van de beroepsgroep. De samenstelling van de responsgroep kon wel vergeleken worden met oudere gegevens, ${ }^{13}$ hetgeen toeliet een algemeen beeld te vormen van mogelijke verschillen met de totale populatie. Zo zijn vrouwen mogelijk oververtegenwoordigd: $57,8 \%$ van de respondenten was vrouw, waar dit volgens (verouderde) gegevens ongeveer $43 \%$ zou zijn in de totale populatie. De heersende tendens van vervrouwelijking van de advocatuur doet evenwel vermoeden dat het aandeel vrouwen vandaag aanzienlijk is gestegen. Ook het aantal Vlaamse advocaten was sterk oververtegenwoordigd tegenover hun Franstalige confraters (78\% Vlaamse advocaten in de steekproef tegenover naar schatting $57 \%$ in de totale populatie). Zoals verwacht waren ook de erkende advocaat-bemiddelaars oververtegenwoordigd (18\% in de steekproef tegenover bijna $4 \%$ in de totale populatie in september 2017). ${ }^{14}$ Ook dit oneven-

11 D. Baarda \& M. De Goede, Basisboek Methoden en Technieken, Groningen: Wolters-Noordhoff 2001, p. 157-158.

12 D. Baarda \& M. De Goede, Basisboek Methoden en Technieken, Groningen: Wolters-Noordhoff 2001, p. 228.

13 Voor Vlaanderen: W. Hardyns, D. Gudders, S. Parmentier, L. Pauwels \& A. Verhage, De Advocatenbarometer 2012/2013 - Een beschrijvende analyse van het profiel van de Vlaamse advocaat, Den Haag: Boom Lemma 2014. Voor Wallonië: F. Heselmans, Baromètre des avocats belges francophones et germanophones - Étude 2010, OBFG 2010, te raadplegen op www.droit.uliege.be/ upload/docs/application/pdf/2012-03/presentation_barometre_2010_heselmans_00340001.pdf (consultatie 30 maart 2018).

14 Het aantal unieke erkende advocaat-bemiddelaars werd afgeleid uit de lijst die publiek beschikbaar is op de website van de Federale Bemiddelingscommissie en op regelmatige basis wordt geactualiseerd. Voor de meest recente lijst, zie www.fbc-cfm.be/nl/zoeken-naar-een-bemiddelaar (consultatie 28 maart 2018). 
Figuur 1 Evolutie van het aantal unieke erkende advocaat-bemiddelaars in België (oktober 2016 - oktober 2017)

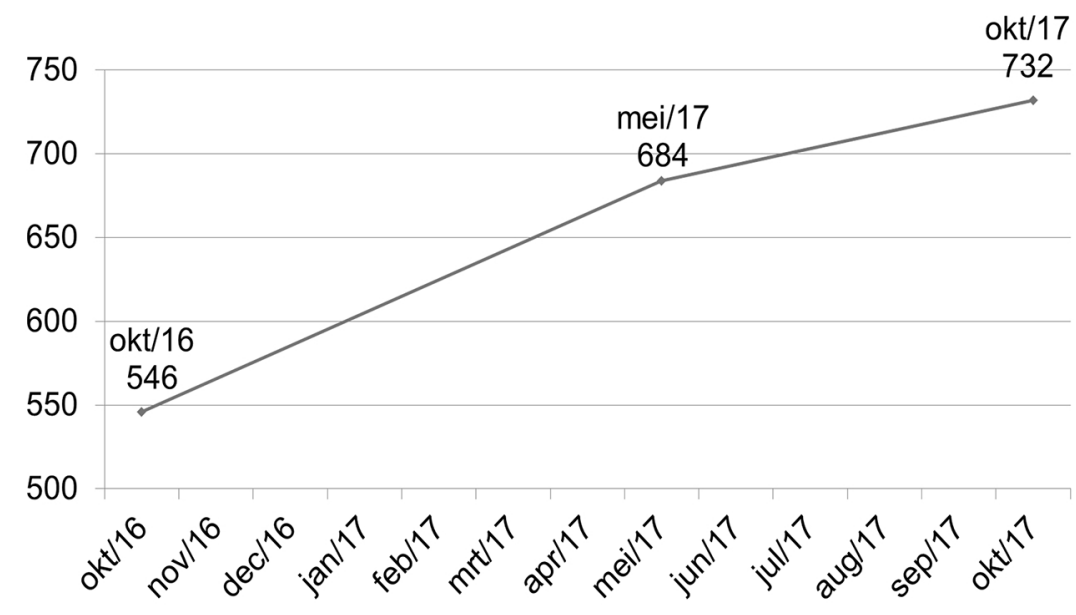

wicht kan in zekere mate worden genuanceerd, nu het aantal advocaat-bemiddelaars op korte tijd sterk lijkt toe te nemen (zie figuur 1). Op één jaar tijd bleek het aantal unieke erkende advocaat-bemiddelaars met maar liefst $34 \%$ te zijn toegenomen.

Hierna volgt een overzicht van een aantal opvallende resultaten uit de bevraging van de Belgische advocatuur over bemiddeling.

\section{Positieve houding, maar ...}

De respondenten werden uitvoerig bevraagd over hun houding ten aanzien van bemiddeling. Daaruit bleek dat $87 \%$ de keuze voor bemiddeling in plaats van een gerechtelijke procedure niet ziet als een teken van zwakte. $83 \%$ ziet in bemiddeling een nuttig alternatief voor het oplossen van conflicten en oordeelt dat bemiddeling complementair kan zijn aan de advocatuur. $71 \%$ geeft aan vertrouwen te hebben in bemiddeling als traject om geschillen op te lossen.

Meer dan $90 \%$ van de deelnemers vond dat er voor hen vandaag een rol is weggelegd in de begeleiding en ondersteuning van de cliënt wanneer die kiest om een bemiddeling op te starten. Tegelijk was het gros van de respondenten van oordeel 
dat er nog ruimte bestaat om de rol van de advocatuur tijdens de bemiddeling in de toekomst te vergroten (85\%) (zie tabel 1). ${ }^{15}$

De resultaten wezen globaal gezien op een behoorlijk positieve houding van de Belgische advocatuur ten aanzien van bemiddeling. Dit kwam - weinig verrassend - sterker naar voren bij advocaten die een opleiding bemiddeling hadden gevolgd $(0.77,95 \%$ CI $(0.54 ; 1.01)) .{ }^{16}$ Ondanks deze positieve houding kon het onderzoek echter een aantal factoren identificeren die de ontwikkeling van bemiddeling in België, in partnerschap met de advocatuur, kunnen bemoeilijken. Hierna worden twee belangrijke factoren onder de aandacht gebracht.

15 Bij de vraagstelling werd een zevenpuntenschaal gebruikt (helemaal niet akkoord - niet akkoord - enigszins niet akkoord - neutraal - enigszins akkoord - wel akkoord - helemaal akkoord) teneinde voldoende nuancering in het antwoord mogelijk te maken. Het gebruik van een reeks antwoordmogelijkheden heeft daarnaast als statistisch voordeel dat verschillen tussen de respondenten beter kunnen worden vastgesteld. Zie D. Baarda \& M. De Goede, Basisboek Methoden en Technieken, Groningen: Wolters-Noordhoff 2001, p. 191. In de overzichtstabel worden de eerste drie antwoordopties gebundeld onder 'niet akkoord', de laatste drie worden gebundeld onder 'akkoord'.

16 De notatie $(B, 95 \%$ CI $(A, C))$ wordt als volgt geïnterpreteerd.

1 De waarde (B) duidt aan in welke mate de geschatte score van een onderzoeksresultaat wijzigt wanneer één variabele afwijkt van een referentieprofiel (i.e. een bepaald profiel dat door verschillende variabelen, zoals geslacht en anciënniteit, wordt gekenmerkt). Er wordt meer bepaald gekeken of de geschatte score wijzigt wanneer slechts één variabele uit het referentieprofiel wijzigt, zodat op basis daarvan een verband kan worden gezocht tussen die ene variabele enerzijds en verschillende uitkomsten op de vragen van de survey anderzijds. Bij de analyse wordt daarvoor eerst een geschatte score van een referentieprofiel berekend (d.i. doorgaans een score op 7 punten, bij de kennistest op 20 punten). Die referentiescore wordt vervolgens gebruikt om significante verschillen weer te geven bij advocatenprofielen die, op één variabele na, hetzelfde profiel hebben als het referentieprofiel. Het onderzoeksresultaat dat naar deze voetnoot verwijst, toont voor (B) een verhoging van de score met 0.77 tegenover het referentieprofiel. Dat betekent dus dat advocaten die wél een opleiding bemiddeling hebben gevolgd, hoger scoren op de stellingen waaruit een positieve houding blijkt in vergelijking met advocaten die hetzelfde profiel hebben, op het gevolgd hebben van de opleiding na.

$295 \%$ geeft het betrouwbaarheidsniveau van de resultaten weer. Dat betekent dat, als het onderzoek 100 keer herhaald zou worden, men bij 95 samples een betrouwbaarheidsinterval $(A, C)$ (zie hierna) zou uitkomen die de onbekende score van de reële populatie omvat. Een betrouwbaarheidsniveau van $95 \%$ is de standaard bij statistisch onderzoek.

$3 \mathrm{CI}(\mathrm{A}, \mathrm{C})$ geeft het betrouwbaarheidsinterval (confidence interval) weer. Rekening houdende met het betrouwbaarheidsniveau, kunnen we zeggen dat de gebruikte methode heeft geresulteerd in het interval (A,C), dat met een waarschijnlijkheid van 95\% de daadwerkelijke score van de populatie bevat. Hieruit blijkt dus ook de foutenmarge van onze geschatte uitkomst (B), met name de grenzen waarbinnen de schatting in realiteit kan afwijken. In de score die naar deze voetnoot verwijst, is het betrouwbaarheidsinterval $(0.54,1.01)$. De waarde $(B)=0.77$ is onze schatting van de waarde van de onbekende score van de populatie, al houden we rekening met een foutenmarge van 0.235 , waardoor de reële score 0.235 lager (i.e. $0.54=(\mathrm{A})$, de ondergrens van het interval) of hoger (i.e. $1.01=(C)$, de bovengrens van het interval) dan (B) kan liggen. Het interval geeft dus weer hoe accuraat we denken dat onze schatting (B) is.

Zie D. Moore, G. Mccabe \& B. Craig, Introduction to the Practice of Statistics, New York: W. H. Freeman and Company 2014, p. 211, 355-357 en 362. 
Tabel 1 Algemene standpunten van Belgische advocaten ten aanzien van bemiddeling

\begin{tabular}{|c|c|c|c|}
\hline Stelling & $\begin{array}{l}\text { Niet } \\
\text { akkoord }\end{array}$ & Neutraal & Akkoord \\
\hline $\begin{array}{l}\text { Kiezen voor bemiddeling in plaats van voor } \\
\text { een gerechtelijke procedure, is een teken van } \\
\text { zwakte }(N=490)\end{array}$ & $86,73 \%$ & $7,55 \%$ & $5,71 \%$ \\
\hline $\begin{array}{l}\text { Bemiddeling is een nuttig alternatief voor } \\
\text { het oplossen van conflicten }(N=490)\end{array}$ & $8,99 \%$ & $7,96 \%$ & $83,06 \%$ \\
\hline $\begin{array}{l}\text { Bemiddeling kan complementair zijn met de } \\
\text { advocatuur }(N=490)\end{array}$ & $6,12 \%$ & $10,61 \%$ & $83,27 \%$ \\
\hline $\begin{array}{l}\text { Ik heb vertrouwen in bemiddeling als traject } \\
\text { om geschillen af te handelen }(N=490)\end{array}$ & $14,29 \%$ & $14,69 \%$ & $71,02 \%$ \\
\hline $\begin{array}{l}\text { Wanneer mijn cliënt kiest een bemiddeling } \\
\text { op te starten onder leiding van een onafhan- } \\
\text { kelijke en onpartijdige bemiddelaar, is er } \\
\text { voor mij nog steeds een rol weggelegd in de } \\
\text { begeleiding van de cliënt }(N=490)\end{array}$ & $4,49 \%$ & $5,31 \%$ & $90,21 \%$ \\
\hline $\begin{array}{l}\text { Er is ruimte om de rol van de advocatuur } \\
\text { binnen de bemiddeling te vergroten }(N= \\
435)\end{array}$ & $3,22 \%$ & $12,18 \%$ & $84,60 \%$ \\
\hline
\end{tabular}

\section{Hardnekkige misverstanden}

Uit de onderzoeksresultaten bleek dat bijna $57 \%$ van de respondenten reeds in één of meerdere hoedanigheden actief betrokken was geweest was bij een bemiddeling (zie figuur 2). 51,6\% van de respondenten gaf aan ooit deelgenomen te hebben als advocaat van een conflictpartij, 14,3\% was reeds actief als advocaatbemiddelaar. Meer dan 33\% had minstens één opleiding tot bemiddelaar gevolgd. Tegelijk gaf meer dan $66 \%$ van de respondenten aan zich in meerdere of mindere mate vertrouwd te voelen met hoe bemiddeling werkt en voelde $61 \%$ zich voldoende geïnformeerd over bemiddeling en de Belgische bemiddelingswet.

Hoewel een meerderheid van de deelnemers een zekere vorm van ervaring had met bemiddeling en zij zichzelf vertrouwd en geïnformeerd voelen, bleek uit de kennistest dat er nog steeds een aantal hardnekkige en wijdverspreide misverstanden overeind blijven. Zo denkt meer dan 31\% dat de bemiddelaar een bindende oplossing voor het conflict kan opleggen wanneer de partijen niet zelf tot een akkoord komen (zie figuur 3 ).

Bijna 20\% dacht dat de bemiddelaar aan de rechter moet rapporteren over het concrete verloop van de bemiddeling. $21 \%$ dacht dan weer dat de rechter de partijen in de huidige juridische context kan verplichten om te bemiddelen alvorens de rechter uitspraak doet over de grond van de zaak, hetgeen (in afwachting van een eventuele invoering van de verplichte bemiddelingspoging in België) vandaag 
Figuur 2 'Bent u ooit al actief betrokken geweest bij een vrijwillige of gerechtelijke bemiddeling in de zin van Deel VII van het Gerechtelijk Wetboek, en zo ja, in welke hoedanigheid / hoedanigheden?' $(N=490)$

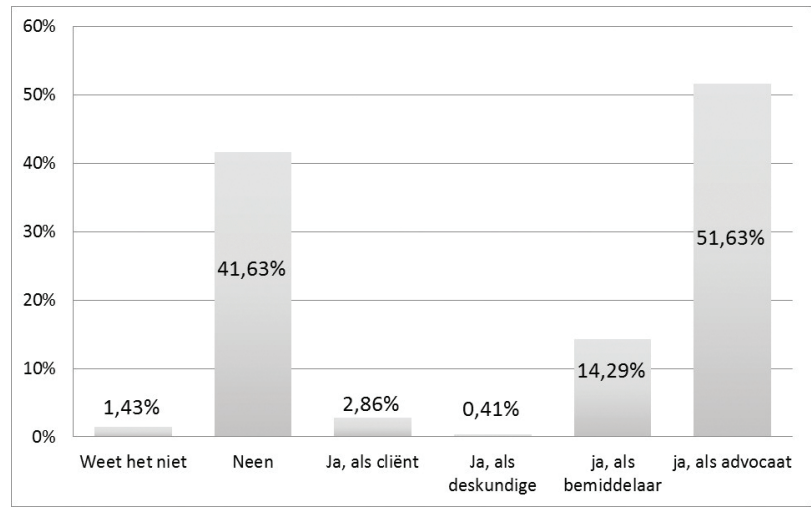

Figuur 3 'Een bemiddelaar zal in eerste instantie de partijen zelf tot een oplossing laten komen en zal pas subsidiair, indien de partijen hier niet in slagen, zelf een oplossing aan de partijen opleggen.' $(J / F / W H N) N=482)$

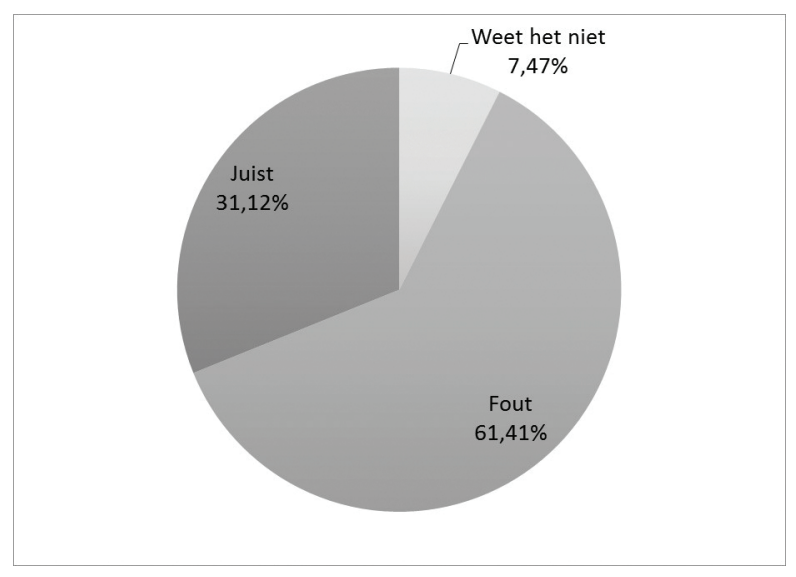

zeker niet het geval is. Nog eens $10,8 \%$ wist niet of een rechter de partijen kan verplichten.

Tot slot denkt 54\% dat ook documenten en mededelingen die bestaan los van de bemiddeling maar verband houden met het geschil (bijv. een huurcontract dat aan de basis ligt van het conflict) onder de vertrouwelijkheid van de bemiddeling vallen en dus later niet kunnen worden aangewend in een gerechtelijke procedure. Dat is naar huidig recht uiteraard een foute veronderstelling: de bemidde- 
ling mag niet misbruikt worden om stukken die bestaan los van de bemiddeling te immuniseren tegen een later gebruik als bewijsstuk in een procedure. ${ }^{17}$

Deze voorbeelden tonen aan dat niet alle advocaten voldoende geïnformeerd zijn over bepaalde essentiële bestanddelen van de bemiddeling, waaronder de vrijwilligheid en vertrouwelijkheid. Die kennis is nochtans cruciaal. Een advocaat zal zijn doorverwijsfunctie naar het meest passende traject pas adequaat kunnen invullen wanneer hij een duidelijk, juist en volledig beeld heeft van de opties die op tafel liggen.

Uit de statistische analyse bleek wel een verband tussen bepaalde variabelen in het profiel van de advocaat enerzijds en het kennisniveau anderzijds. Zo lag de geschatte score op de kennistest lager voor advocaten zonder enige ervaring met bemiddeling dan voor advocaten die - behoudens verschillen in ervaring met bemiddeling - hetzelfde profiel hadden $(-1.05,95 \%$ CI $(-1.71 ;-0.38))$. Het hoeft niet te verbazen dat advocaten die een opleiding tot bemiddelaar hebben gevolgd dan weer een aanzienlijk hogere geschatte score hadden (3.21, 95\% CI (2.41; 4.00)). Ook advocaten die een vak over ADR hadden gevolgd in de rechtenopleiding scoorden hoger $(1.29,95 \%$ CI $(0,51 ; 2.07))$. Hoewel deze resultaten geen uitsluitsel geven over causaliteit, lijkt het aannemelijk dat het onderwijs een grote rol en verantwoordelijkheid heeft in het aanbrengen van kennis over de verschillende conflictoplossingsmethoden. Uit de resultaten bleek trouwens dat ook binnen de advocatuur een aanzienlijk deel van de respondenten een meerwaarde ziet in (verhoogde) aandacht voor ADR in het onderwijs. 51\% oordeelde dat de Belgische advocaat verplicht een basisopleiding 'bemiddelingsvaardigheden' zou moeten volgen. Bijna $65 \%$ vond dat er ook in de balielessen meer aandacht moest worden geschonken aan ADR. 67\% procent van de respondenten oordeelde zelfs dat op élk onderwijsniveau (niet alleen hoger, laat staan juridisch onderwijs, maar zelfs vanaf het kleuteronderwijs) meer aandacht moet worden besteed aan conflicthantering en de verschillende manieren waarop een conflict kan worden opgelost.

Op basis van de analyses kon verder worden onderzocht of een gebrek aan kennis inderdaad in verband kan worden gebracht met een uitgesproken negatieve houding ten aanzien van bemiddeling (en mogelijke weerstand tot gevolg). De analyses toonden aan dat respondenten met een hoger kennisniveau ook positiever staan tegenover bemiddeling, maar het effect was uiterst klein $(0.0375,95 \%$ CI (0.0141; 0.0609)). Er kon bijgevolg geen sterk verband worden vastgesteld tussen beperkte kennis van en een opvallend negatieve houding ten aanzien van bemiddeling.

\section{Bemiddeling als broodroof}

Een van de voornaamste struikelblokken die belemmert dat de advocaat bemiddeling omarmt, zou gelegen zijn in de perceptie dat bemiddeling de inkomsten van

17 K. Andries, 'A secret shared is a secret lost'? Bedenkingen bij de Belgische bewijsuitsluiting voor bemiddeling, TMD 2011, afl. 3, 53. 
en de werkgelegenheid voor de advocaat bedreigt. Het is evident dat de financiële belangen van de advocaat een grote impact hebben wanneer de cliënt advies vraagt over het te kiezen traject.

Het onderzoek lijkt in elk geval te bevestigen dat bemiddeling in het (financieel) vaarwater van de advocatuur komt. Hoewel ruim $83 \%$ stelt dat bemiddeling complementair kan zijn aan de advocatuur, vreest $28 \%$ dat bemiddeling vandaag een nadelig effect heeft op de inkomsten van de advocatuur. Bijna $29 \%$ ziet bemiddelaars als concurrenten voor de advocaat. Wanneer bemiddeling in de toekomst op grotere schaal gebruikt zou worden, verwacht zelfs $41 \%$ dat dit een negatieve impact zal hebben op de werkgelegenheid binnen de advocatuur. Hoewel deze resultaten lager waren dan initieel werd verwacht, ziet een aanzienlijk aandeel van de respondenten bemiddeling dus nog steeds als een financiële bedreiging. In tijden waarbij naar schatting een derde van de Belgische advocaten zwarte sneeuw ziet(!), ${ }^{18}$ heeft deze angst voor inkomstenverlies bijna onvermijdelijk een nefast effect op de doorverwijzing naar en ontwikkeling van bemiddeling in het Belgische juridische landschap. Ook de advocaat wil brood op de plank en zal daardoor niet geneigd zijn om door te verwijzen naar alternatieve trajecten, wanneer hij vreest daardoor in een (nog) benarde(re) financiële toestand verzeild te geraken. Het onderzoek toont aan dat deze vrees niet volledig ongegrond is. Van de advocaten die aangaven in het verleden reeds cliënten geadviseerd te hebben om een bemiddeling op te starten (70,9\%), had maar liefst een derde globaal gezien het gevoel dat het advies om te bemiddelen er al eens toe had geleid dat zijn of haar diensten als advocaat niet meer nodig waren voor de cliënt (zie figuur 4). Daarnaast had 43,5\% van de advocaten die reeds bemiddeling hadden geadviseerd het gevoel dat dit advies al eens geleid had tot inkomstenverlies voor zichzelf (zie figuur 5).

Het hoeft niet te verbazen dat bemiddeling leidt tot lagere inkomsten voor de advocaat die de bemiddeling aanbeveelt (i.e. de partijondersteuner). Een van de intrinsieke voordelen van een (succesvolle) bemiddeling is nu eenmaal dat zij mogelijk resulteert in een tijds- en kostenbesparing, hetgeen een directe impact heeft op het ereloon van de advocaat. ${ }^{19}$

Dat meer dan een derde van de advocaten al eens de indruk had dat hun diensten niet meer nodig waren na hun advies om de bemiddeling op te starten, is daarentegen minder makkelijk te verklaren. Het is mogelijk dat de cliënt net door het voorstel om te bemiddelen het vertrouwen verliest in de strijdvaardigheid van de raadsman, gezien een 'zachtere' aanpak van het geschil niet strookt met de klas-

18 Hoewel exacte cijfers ontbreken, zou naar schatting een derde van de advocaten een inkomen hebben dat rond of onder het leefloon schommelt. Zie M. Vandersmissen, Advocaten onder de armoedegrens: 'Zelfs hun lidgeld van de balie kunnen ze niet meer betalen', www.knack.be/ nieuws/belgie/advocaten-onder-de-armoedegrens-zelfs-hun-lidgeld-van-de-balie-kunnen-ze-nietmeer-betalen/article-normal-960657.html (consultatie 26 maart 2018).

19 G. De Palo, A. Feasley \& F. Orecchini, Quantifying the cost of not using mediation - a data analysis (nota Europees Parlement), Brussel, Europese Unie, Directoraat-Generaal Intern Beleid Afdeling Beleid C, 2011, www.europarl.europa.eu/document/activities/cont/201105/ 20110518ATT19592/20110518ATT19592EN.pdf (consultatie 3 april 2018), p. 13-16. 
Figuur 4 'Heeft u globaal gezien het gevoel dat uw advies om te bemiddelen er al eens toe geleid heeft dat uw diensten als advocaat niet meer nodig waren voor uw cliënt?' $(N=329)$

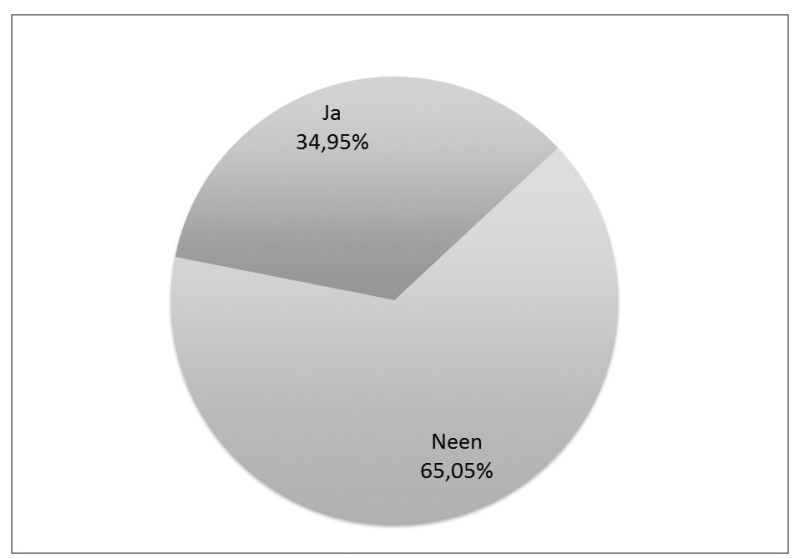

Figuur 5 'Heeft u globaal gezien het gevoel dat uw advies om te bemiddelen al eens geleid heeft tot inkomstenverlies voor uzelf?' $(N=329)$

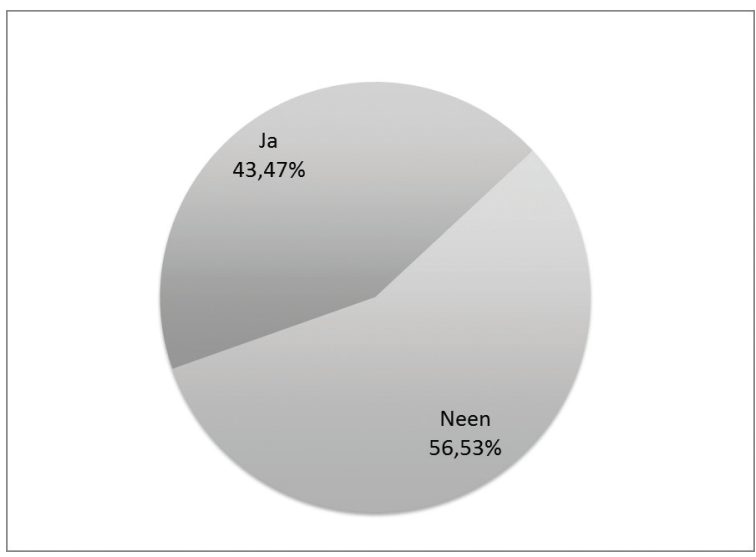

sieke rol van de advocaat-gladiator. ${ }^{20}$ Wanneer de cliënt geen heil ziet in een buitengerechtelijke oplossing ('want met de tegenpartij valt toch niet te praten'), zou dat voldoende kunnen zijn om een andere raadsman aan te stellen die de verwachtingen van de cliënt invult. Het is ook denkbaar dat de diensten van de raadsman overbodig worden geacht, omdat de conflictpartijen beroep doen op een bemiddelaar met juridische achtergrond, die vanuit de perceptie van de cliënt voldoende kennis in huis heeft om tot een sluitend akkoord te komen.

20 'Many court lawyers will say that the name of the dispute game is gladiatorial combat, and any thoughts of greater cooperation amongst warring parties are naive and misplaced.' Zie R. Susskind, The End of Lawyers? Rethinking the Nature of Legal Services, New York: Oxford University Press 2010, p. 182. 
Een derde mogelijke verklaring kan zijn dat de bemiddelaar de advocaten niet of onvoldoende bij de bemiddeling betrekt. Uit gesprekken met verschillende actoren uit de bemiddelingswereld (zowel met als zonder juridische achtergrond) bleek in elk geval meermaals dat er een sterk spanningsveld bestaat tussen juristen en niet-juristen. Sommige 'derde groep'-bemiddelaars (i.e. bemiddelaars die geen advocaat of notaris zijn) zouden de aanwezigheid van een advocaat eerder als een belemmering zien dan als een meerwaarde. Het onderzoek bracht ook een gespannen sfeer aan het licht tussen advocaat-bemiddelaars en advocaat-partijondersteuners. Hoewel hun rol fundamenteel verschilt in de bemiddeling, zou een gevoel van concurrentie tussen de betrokken advocaten de bemiddeling bemoeilijken. Het lijkt aannemelijk dat een schijnbaar moeizame werkrelatie tussen bemiddelaar (of die nu jurist is of niet) en advocaat-partijondersteuner de betrokkenheid van die laatste ernstig onder druk zet. ${ }^{21}$ Dat is bijzonder jammer, net omdat een actieve betrokkenheid van de advocaat-partijondersteuner een aanvullende waarborg kan zijn die de geïnformeerde toestemming bij een eventueel akkoord garandeert, en die kan bijdragen tot een kwalitatieve en sluitende redactie van het schriftelijk akkoord.

De hoger vermelde cijfers leggen de vinger op de wonde. Het is in elk geval begrijpelijk dat niet iedereen bereid is om in eigen vel te snijden en dat sommige advocaten vanuit die invalshoek weigerachtig zijn om een zaak 'uit handen te geven' aan een bemiddelaar.

\section{Het wetsontwerp-Geens en het draagvlak daarvoor binnen de advocatuur}

In het laatste deel van de enquête werd het draagvlak onderzocht voor bepaalde denkpistes die beogen het gepast gebruik van bemiddeling aan te wakkeren. Die resultaten zijn uitermate relevant, nu bepaalde van die denkpistes uitgewerkt werden in het wetsontwerp van minister van Justitie Koen Geens, dat begin februari 2018 in het Belgisch federaal parlement werd ingediend. ${ }^{22}$ De Belgische advocaat lijkt alleszins hervormingsgezind, nu ruim $68 \%$ van de respondenten

21 Uit de Bemiddelingsbarometer 2016 (die tot stand kwam met medewerking van de auteur), blijkt dat de advocaat voornamelijk in familiale geschillen zelden betrokken wordt bij de bemiddeling. Bij burgerlijke en handelsgeschillen is dit vaker het geval, al is het ook daar verre van de uitzondering dat advocaten afwezig zijn bij het bemiddelingsverloop. Zie bMediation, Bemiddelingsbarometer 2016, www.bmediation.eu/images/stories/publications/bemiddelingsbarometer \%202016\%20nl\%20final.pdf (consultatie 3 april 2018), 16. Deze bevindingen werden bevestigd in recent doctoraal onderzoek, waaruit bleek dat zelfs de (familiale) bemiddelingsopleidingen de bijstand van een advocaat zouden afraden. In commerciële geschillen zouden bemiddelaars inderdaad positiever staan tegenover de meerwaarde van de bijstand door de advocaat. Zie W. Hensen, Justitie en bemiddeling - Een bevraging en analyse aangaande de mogelijkheden en knelpunten van de gerechtelijk bemiddeling, onuitg. doctoraatsthesis UHasselt, 2017, p. 192-193, nrs. 405-408.

22 Wetsontwerp houdende diverse bepalingen inzake burgerlijk recht en houdende wijziging van het Gerechtelijk Wetboek met het oog op de bevordering van alternatieve vormen van geschillenoplossing, Parl.St. Kamer 2017-18, nr. 54-2919/1. Voor een bondige bespreking van de krachtlijnen, sterktes en valkuilen uit het wetsontwerp, zie T. Wijnant, Alternatieve geschillenoplossing: opgepast voor de valkuilen, Juristenkrant 2018, afl. 364, 12. 
Figuur 6 'Vindt u dat overheidsorganen en publiekrechtelijke rechtspersonen meer beroep moeten kunnen doen op bemiddeling om hun conflicten af te handelen?' $(N=416)$

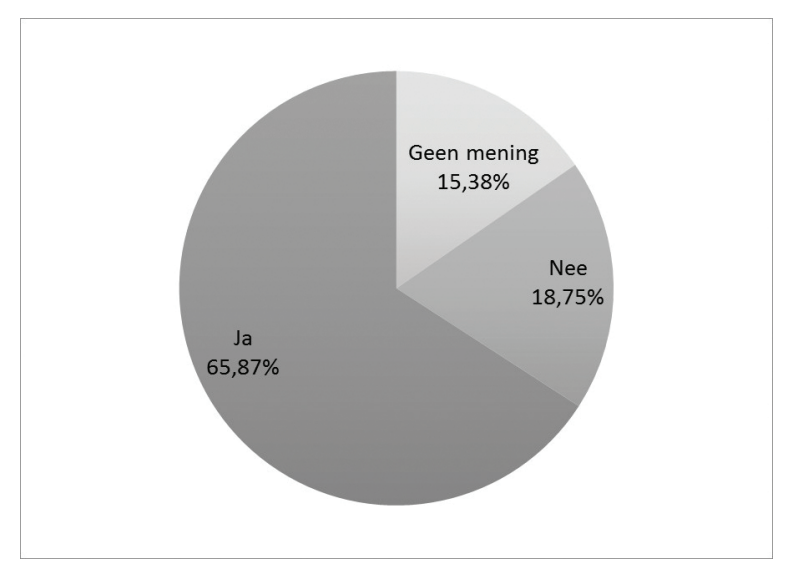

oordeelt dat het gebruik van bemiddeling moet worden gestimuleerd. Hierna worden enkele voorstellen uit het wetsontwerp doorgelicht aan de hand van de onderzoeksresultaten.

Het wetsontwerp voorziet onder meer in een uitbreiding van het toepassingsgebied van de bemiddelingswet, zodat ook publiekrechtelijke rechtspersonen voortaan effectief als conflictpartij bij een bemiddeling kunnen optreden. Dat lijkt een goede zaak: de overheid geeft het goede voorbeeld en tegelijk kunnen heel wat overheidsgeschillen hun weg vinden naar alternatieve trajecten die doeltreffende en tijdbesparende oplossingen kunnen bieden. Dat is in het voordeel van zowel burger als overheid. Bemiddeling met de overheid is evenwel niet vanzelfsprekend, omdat die in een verticale verhouding met de burger opereert en private belangen moet afwegen tegen het algemeen belang. Bovendien dreigt een domino-effect, waarbij een bemiddeld akkoord met één rechtzoekende (bijv. in de context van een grootschalig infrastructuurproject) de onvrede van andere burgers tot gevolg kan hebben. De vertrouwelijkheid van de bemiddeling mag ten slotte in geen geval de transparantie van het overheidsoptreden onaanvaardbaar belemmeren.

De Belgische advocaat ziet desondanks heil in bemiddeling met de overheid: een overtuigende meerderheid oordeelt dat de overheid beroep moet kunnen doen op bemiddeling om zijn conflicten af te handelen (zie figuur 6).

Het wetsontwerp voorziet daarnaast in een wettelijke basis voor de collaboratieve onderhandelingen (collaborative law). Dat zijn vertrouwelijke en rechtstreekse onderhandelingen, waarbij de conflictpartijen worden bijgestaan door hun collaboratieve (daartoe getrainde) advocaten. Daarbij staat een respectvolle en belangengerichte benadering van het conflict centraal. Bijzonder is dat de collaboratieve advocaat gehouden is om zich terug te trekken, mochten de onderhandelin- 
Figuur 7 'Lijkt Collaborative Law als geschillenoplossingsmethode voor $u$ werkbaar in België?' $(N=415)$

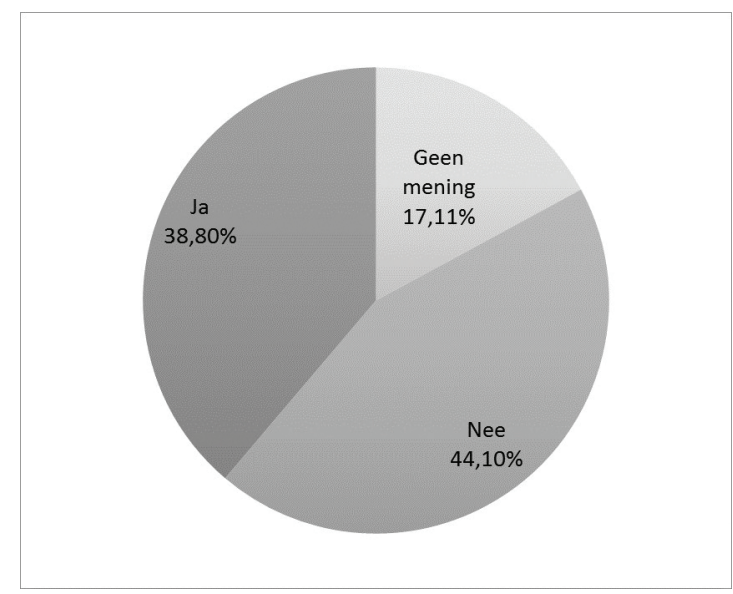

gen mislukken. ${ }^{23} \mathrm{Hij}$ mag zijn cliënt naderhand dus niet meer in rechte verdedigen. Deze diskwalificatieregel moet de collaboratieve advocaat ertoe aanzetten zich ten volle in te zetten voor een constructief verloop van de onderhandelingen. De invoering van de collaboratieve onderhandelingen in het Gerechtelijk Wetboek toont aan dat de Belgische overheid advocaten sterker wil betrekken bij alternatieve geschillenoplossing, wat zeer toe te juichen is. Men moet evenwel rekening houden met bepaalde reële risico's. Zo zou een collaboratieve advocaat ten onrechte de onderhandelingen kunnen rekken uit angst voor inkomstenverlies.

Nadat aan de respondenten werd uitgelegd wat collaboratieve onderhandelingen precies inhouden, werd hun gevraagd of deze geschillenoplossingsmethode voor hen werkbaar lijkt in België. De resultaten waren enigszins verdeeld (zie figuur 7). Dat slechts een minderheid zich achter de collaboratieve onderhandeling schaart, hoeft evenwel niet problematisch te zijn. Niet alle advocaten moeten immers in de toekomst collaboratief te werk gaan. Het draagvlak lijkt evenwel groot genoeg om de opkomst van collaboratieve onderhandelingen in België te dragen.

Een zeer verregaand voorstel uit het wetsontwerp betreft de verplichte bemiddelingspoging die door de rechter kan worden opgelegd, waardoor de Belgische regering het heilig huisje van de vrijwilligheid van de bemiddeling op zijn grondvesten doet daveren. De rechter kan de bemiddelingspoging ambtshalve of op verzoek van één partij bevelen, weliswaar enkel nadat de partijen gehoord werden en enkel bij het begin van de procedure. Het beginsel dat partijen te allen tijde een einde mogen maken aan de aangevangen bemiddeling blijft evenwel onverminderd van kracht. De vooropgestelde verplichte bemiddelingspoging roept welis-

23 Zie hierover A. D’Herde, Collaboratief recht in België: een veelbelovende ADR-methode voor de Vlaamse advocaat, TMD 2016, afl. 3, 39-47. 
Figur 8 'Vindt u dat de Belgische wetgever minstens in bepaalde materies een verplichte bemiddelingspoging zou moeten invoeren in het Gerechtelijk Wetboek?' (N = 415)

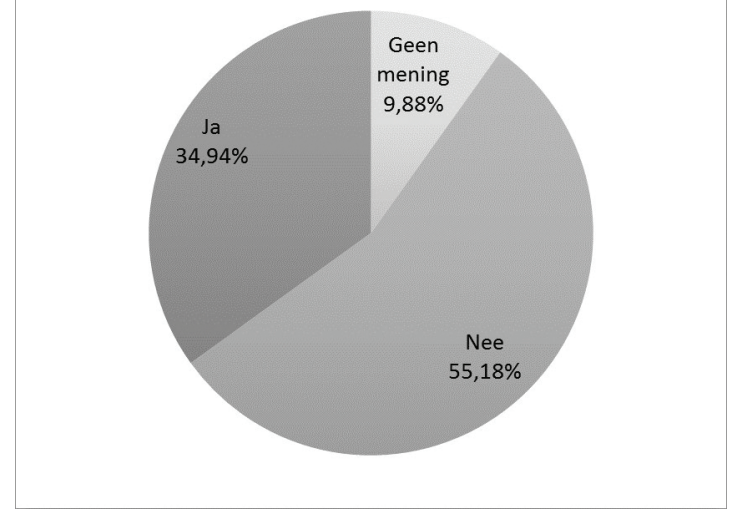

waar vragen op. Zo kan men zich afvragen welke inspanning men minimaal mag verwachten van de partij die tot een verplichte bemiddelingspoging gedwongen wordt. Of een dergelijke verregaande vorm van dwang op langere termijn de bemiddelingspraktijk in België zal bevorderen, is nog maar de vraag.

Uit het onderzoek blijkt (weinig verrassend) dat een ruime meerderheid van de advocaten zich verzet tegen de invoering van een verplichte bemiddelingspoging (zie figuur 8). Hierbij moet worden onderlijnd dat de advocaten niet bevraagd werden over de verplichte gerechtelijke bemiddeling, zoals dit in het wetsontwerp wordt voorgesteld, maar wel over de mogelijkheid om een verplichte voorafgaande bemiddelingspoging op te leggen waarbij partijen in bepaalde materies een bemiddelingspoging moeten ondernemen vooraleer zij toegang krijgen tot de rechter. Desondanks lijkt het aannemelijk dat de resultaten in dezelfde lijn zouden liggen wanneer naar de invoering van een verplichte gerechtelijke bemiddelingspoging werd gevraagd. ${ }^{24}$ De resultaten stemmen in elk geval overeen met de nota van de Orde van Vlaamse Balies, die begin maart 2018 tijdens een hoorzitting van de Commissie Justitie van de Kamer werd behandeld en waarbij de OVB het absolute karakter van de vrijwilligheid van de bemiddeling verdedigt. ${ }^{25}$

24 Dit ligt in lijn met empirische onderzoeksresultaten uit recent doctoraatsonderzoek betreffende de gerechtelijke bemiddeling. Zie W. Hensen, Justitie en bemiddeling - Een bevraging en analyse aangaande de mogelijkheden en knelpunten van de gerechtelijk bemiddeling, onuitg. doctoraatsthesis UHasselt, 2017, p. 210-211, nr. 440.

25 Orde van Vlaamse Balies, Nota betreffende het wetsontwerp van 5 februari 2018 houdende diverse bepalingen inzake burgerlijk recht en houdende wijziging van het Gerechtelijk Wetboek met het oog op de bevordering van alternatieve vormen van geschillenoplossing, 6 maart 2018, www.ordeexpress.be/UserFiles/ArtikelDocumenten/Nota\%200VB\%20wetsontwerp \%205\%20februari\%202018\%20bemiddeling\%20en\%20collaboratieve\%20onderhandeling.pdf (consultatie 29 maart 2018), 1 en 6-7. 


\section{Conclusie}

Uit dit tussentijds rapport blijkt dat de Belgische advocaat minder negatief staat tegenover bemiddeling dan aanvankelijk werd gedacht. Een grote meerderheid ziet in bemiddeling een nuttig alternatief voor het oplossen van conflicten en oordeelt dat bemiddeling complementair kan zijn aan de advocatuur. Bemiddeling wordt daarbij niet gezien als een zwaktebod. De advocaat ziet zichzelf in elk geval vandaag al een rol spelen in het kader van een bemiddeling, al is er nog marge om die rol in de toekomst te vergroten.

Ondanks deze eerder positieve houding kunnen tegelijk een aantal kanttekeningen worden gemaakt. Uit het onderzoek bleek immers dat er nog steeds een aantal struikelblokken ligt op de weg naar een meer gepast gebruik van bemiddeling. Zo bestaat er nog steeds een aantal grote misverstanden binnen de advocatuur. Als we willen dat de advocaat van de toekomst zijn cliënt begeleidt naar het meest gepaste traject voor geschiloplossing, dan moeten advocaten natuurlijk wel goed geïnformeerd zijn. Het is evident dat een advocaat die denkt dat een bemiddelaar een bindende beslissing kan opleggen en dat zo overbrengt naar de cliënt, zijn doorverwijsfunctie niet op een behoorlijke manier kan vervullen. Tegelijk zien heel wat advocaten bemiddeling nog steeds als een concurrerende activiteit die het inkomen en de werkgelegenheid binnen de advocatuur bedreigt. Die vrees zou weleens gegrond kunnen zijn, nu advocaten met ervaring in de doorverwijzing naar bemiddeling aangeven dat zij ten gevolge van die doorverwijzing werk en bijgevolg inkomsten aan hun neus zagen voorbijgaan.

Ondanks het feit dat een aantal impedimenta konden worden geïdentificeerd, is het niet zo dat de Belgische advocaat niet hervormingsgezind zou zijn op het gebied van alternatieve geschillenoplossing. Niet alle denkpistes worden echter als wenselijk of haalbaar onthaald. Waar er een werkbaar draagvlak lijkt te bestaan voor bemiddeling met de overheid en collaboratieve onderhandelingen, lijkt dit problematischer voor de invoering van de verplichte bemiddelingspoging in België.

Dit eerste rapport licht slechts een tipje van de sluier. In de komende maanden worden de data uitvoeriger geanalyseerd. Een uitgebreider verslag van de onderzoeksresultaten volgt ${ }^{26}$ en zal als basis dienen voor concrete suggesties ter optimalisering van de buitengerechtelijke bemiddeling, met een bijzondere focus op de faciliterende rol van de Belgische advocaat. 